\title{
The Effect of ODOI On Innovative Work Behavior and Employee Performance
}

\author{
Luhgiatno $^{1, *}$, Widaryanti ${ }^{2}$, Aprih Santoso $^{3}$ \\ 1,2 Sekolah Tinggi Ilmu Ekonomi Pelita Nusantara Semarang \\ ${ }^{3}$ Departemen Manajemen, FE Universitas Semarang \\ Email Address: \\ luhgiatno_smg@yahoo.co.id ${ }^{1}$;wdr.yanti@gmail.com²; aprihsantoso@usm.ac.id ${ }^{3}$ \\ ${ }^{*}$ Corresponding author
}

\begin{abstract}
The research objective is to develop optimal distinctive open innovation (ODOI) concepts, propositions and indicators as well as to test them empirically. ODOI was formed using a synthesis method of two concepts, namely optimal characteristics, derivatives of social identity theory, and open innovation derived from innovation theory. Quantitative empirical testing using SEM on primary data, the PTS lecturers in the LLDIKTI VI Central Java environment were 190 respondents. The test results show that ODOI is able to mediate the effect of innovative work behavior on improving employee work performance. Innovative work behavior has an effect on increasing ODOI and has an effect on improving employee work performance. ODOI has an effect on improving employee work performance.
\end{abstract}

Keywords: ODOI; innovative work behavior; employee work performance.

\begin{abstract}
Abstrak: Tujuan penelitian untuk mengembangkan konsep inovasi terbuka dengan kekhasan yang optimal (ODOI), proposisi dan indikator serta pengujiannya secara empiris. ODOI dibentuk menggunakan metode sistesis dari dua konsep yaitu kekhasan optimal, turunan dari teori identitas sosial, dan inovasi terbuka turunan dari teori inovasi. Pengujian empiris secara kuantitatif menggunakan SEM terhadap data primer, pada dosen PTS dilingkungan LLDIKTI VI Jawa Tengah berjumlah 190 responden. Hasil pengujian didapat bukti bahwa ODOI mampu memediasi pengaruh perilaku kerja inovatif terhadap peningkatan kinerja kerja karyawan. Perilaku kerja inovatif berpengaruh terhadap peningkatan ODOI serta berpengaruh terhadap peningkatan kinerja kerja karyawan. ODOI berpengaruh terhadap peningkatan kinerja kerja karyawan.
\end{abstract}

Kata kunci: ODOI; Perilaku kerja inovatif; Kinerja kerja karyawan.

\section{INTRODUCTION}

A company is able to win the competition if it has qualified human resources (Altındağa and Kösedağı, 2015). Human resources are a complex part to be managed and developed (Mikhaylov et al., 2014), but companies must strive to develop the potential of each of their human resources. The company develops HR through continuous learning, 
retaining programs, training, and others. It is intended that the performance of each employee can increase.

Employee performance is the target of the task and how to perform the task. Employee performance is an indicator of corporate success (Rusu et al., 2016; Sadikoglu and Zehir, 2010). The better the employee's performance, the better the corporate performance will be. Companies must strive to improve the performance of their employees. Employee performance should not be average performance (Iqbal and Asrarul-Haq, 2018). Every company activity must be focused on improving performance in order to compete (Ebrahimi et al., 2014). Employee performance appraisal is needed in the context of challenges from both internal and external factors (Rusu et al., 2016) and must be adjusted to the existing context (St-Onge and Morin, 2009). Employee performance is an important part of achieving sustainable competive advantage (Choudhary et al., 2017)

The innovative behavior of employees is an important part of improving their performance (Ardyan, 2016; Sadikoglu and Zehir, 2010; Schepers et al., 2016; Sugiyarti and Ardyan, 2017; Tsinopoulos et al., 2019). Tsinopoulos et al. (2019) explain that innovation activities within the company will have an impact on the creation of something new. Companies are trying to increase their innovation activities, because they have hopes they want to achieve. The purpose of this research is to develop a concept optimal distinctive open innovation (ODOI) and propositions related to this concept, and to test it empirically its effect on innovative work behavior and employee work performance.

\section{THEORETICAL REVIEW}

Optimal Distinctive Open Innovation. One of the organizational priorities is innovation (Slater et al., 2014). Innovation can measure a company's ability to compete. Innovation can be defined as a company's ability to convert ideas into commercial value (Chen et al., 2012). In its development, the company seeks to emphasize innovation on open innovation. The company strives to implement open innovation in each of its activities (Cassiman and Valentini, 2016). Open innovation is able to accelerate the maximization of company profits (Van De Vrande et al., 2009). The development of open innovation is very close to the involvement of external factors in developing new products (Burcharth et al., 2017).

Optimal distinctive theory (ODT) is a social psychological theory proposed by Fritz Heider (Pownall et al., 2019). ODT is related to human efforts in looking for different things within the group at the individual level (Leonardelli et al., 2010). Every individual needs different needs. These differentiated needs are an important part of satisfying their needs. They need a distinctive optimal. the optimal peculiarity occurs at the equilibrium point of contact between one's needs for assimilation and differentiation being met, so that there is identification within the group to be strong. Empirical research on optimal distinctive focuses on the relationship between group size and group identification rather than building perceptual traits to meet assimilation and differentiation needs (Badea et al., 2010). Optimal distinctive theory explains why a person identifies a group that enables them to simultaneously satisfy the need for: 1) assimilation, that is, a sense of belonging that attracts people to be part of a group and 2) differentiation or desire to feel different from others. 
ODOI is a model for developing employee skills in order to create superior and unique creative ideas, through different creativity, dynamic interactions, harmonization of cooperation, information exchange, unlimited thinking, and relationship complexity. Distinctive competence is the specific ability of a company/organization for its resources. A distinctive and unique approach to workforce management (which is one of the organizational resources) is an effort to achieve competitive advantage, develop a workforce strategy, so that the workforce will be able to have a high commitment by using an integrated cultural structure, as well as structural with personnel techniques (Vähäsantanen and Eteläpelto, 2009); (Messmann and Mulder, 2011).

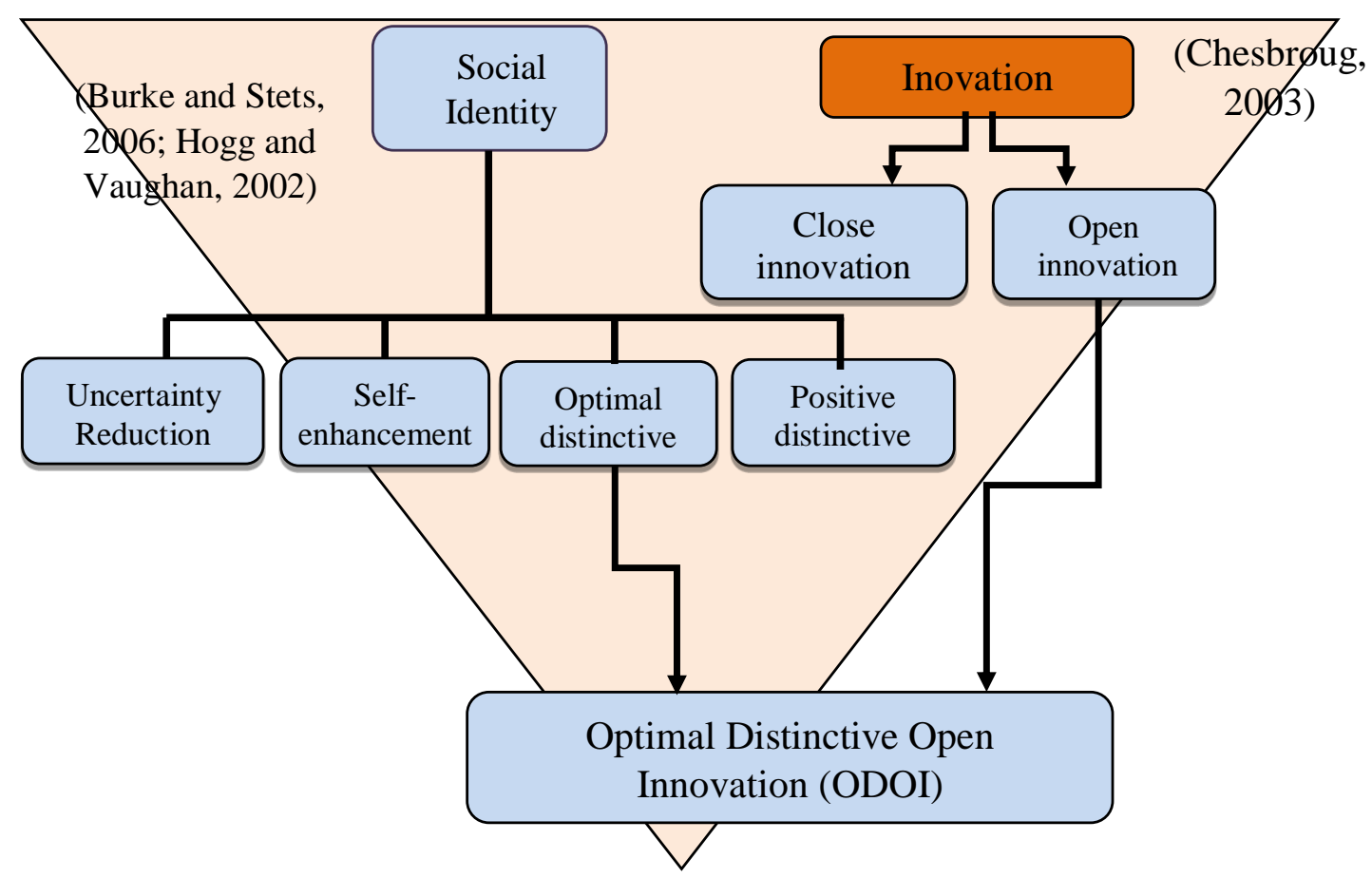

Figure 1. Theory and Basic Concepts of Concept Development ODOI Source: Luhgiatno, 2020

Optimal distinctive open innovation (ODOI), is the expertise of employees in creating superior and unique creative ideas, through different creativity, dynamic interaction, harmonization of cooperation, exchange of information, thinking without boundaries, and the complexity of relationships (Luhgiatno, 2020). The dimensions developed in this research are creativity creates value that is different, dynamic interactions, harmonizing cooperation, exchanging information, thinking without limits, and relationship complexity. The ODOI indicator, which is the result of a synthesis of optimal specificity indicators and open innovation indicators, is as shown in the following table. 
Table 1. Synthesis of the ODOI Concept Indicators

\begin{tabular}{|c|c|c|}
\hline Indicator Optimal Distinctive & Indicator Open Innovation & $\begin{array}{c}\text { Synthesis results of concept } \\
\text { indicators ODOI }\end{array}$ \\
\hline $\begin{array}{l}\text { 1. Assimilation, a sense of } \\
\text { belonging that attracts }\end{array}$ & $\begin{array}{l}\text { 1. Ideas and knowledge from outside } \\
\text { actors }\end{array}$ & $\begin{array}{l}\text { 1. Creativity creates value that } \\
\text { is different }\end{array}$ \\
\hline people to be part of a group & 2. Organizations open up to present & 2. Dynamic interactions \\
\hline \multirow{2}{*}{$\begin{array}{l}\text { 2. Differentiation or desire to } \\
\text { feel different from others }\end{array}$} & new flows of knowledge that have & 3. Harmonization cooperation \\
\hline & value and come from outside the & 4. Information exchanging \\
\hline \multirow[t]{2}{*}{ 3. Satisfaction as needed } & organization to create opportunities. & 5. Thinking without limits \\
\hline & $\begin{array}{l}\text { 3. Combination with external } \\
\text { technology to optimize internal } \\
\text { potential }\end{array}$ & 6. Relationship complexity \\
\hline
\end{tabular}

Source: Luhgiatno, 2020

Innovative Work Behavior. Innovation is a concept that continues to develop from time to time; the current trend of success shows the impact of innovation. Innovation has an impact on the organization and creativity where innovation comes from, both individuals and organizations so that many organizations or companies always create situations to create innovation in the organization. (Robbins and Judge, 2015) define innovation as new ideas (novelty) that are applied to improve products/services and processes. Innovation is very important for an organization/company to continue to compete and successfully achieve its goals (Smith and Tushman, 2005). The current or future competition in the market is getting tighter, and the threats that occur continue to increase with the presence of new competitors. Continuous differentiation and innovation by employees can inspire to promote and implement new ideas as an important strategy to gain a competitive advantage. Innovation management is needed because fresh ideas will continue to be born in the company and abundant. The existence of these ideas must be arranged and arranged systematically so that there is no confusion. This innovation that must be carried out systematically, efficiently and sustainably requires a system to organize these ideas in a more structured manner. Innovative work behavior is defined as behavior that leads to the initiation and application (in work, group, or organizational roles) of new and useful ideas from a process, product, or procedure (Farr and Ford, 1990). Thus, innovative work behavior can be defined as a multidimensional and comprehensive construct that captures all employee behavior that can contribute to the innovation process (De Jong and Hartog, 2008).

Employee work performance. Employee work performance is the result achieved by employees according to certain criteria that apply to a particular job. Employee work performance is a function of the interaction between ability and motivation, (Robbins and Judge, 2015). Performance is the achievement of a task. The term task comes from thinking about the activities required by workers. Performance includes aspects of business, loyalty, potential, leadership and morale. Performance is seen from three elements, namely: the behavior shown by a person at work, actual results or results achieved by workers, and an assessment of factors such as motivation, commitment, initiative, leadership potential, and morale. Employee performance indicators according to (Robbins and Judge, 2015) are knowledge, abilities and skills at work/ competence, work attitudes expressed in enthusiasm, commitment and motivation, work quality, interaction, 
for example, communication skills and the ability to relate to others in a team. A person exhibits behaviors at work, such as innovative work behavior. Innovative employee work behavior is an important part of improving their performance (Ardyan, 2016; Sadikoglu and Zehir, 2010; Schepers et al., 2016; Sugiyarti and Ardyan, 2017; Tsinopoulos et al., 2019).

Relationship between ODOI, Innovative Work Behavior and Employee Performance. In the world of education, innovation and innovative behavior are important issues. Lecturers as part of an educational institution have a very crucial role. Lecturers need to have a clear vision and have awareness and knowledge of innovation and how to make it happen (Ferrari et al., 2009). It takes good dedication for each lecturer in order to implement this. In order to promote change and innovation and encourage lecturers to be involved, an understanding of how a lecturer experiences in teaching is needed (Vähäsantanen and Eteläpelto, 2009).

Optimal distinctive open innovation, is a model for developing employee skills in order to create superior and unique creative ideas, through different creativity, dynamic interactions, harmonization of cooperation, exchange of information, thinking without boundaries, and relationship complexity. Distinctive competence is the specific ability of a company/organization. Specific actions will be taken by the company in order to perform activities that are better than its competitors. A company that has strength will not be easily imitated by a competing company, this is seen as a company that has a distinctive competence. There are two distinctive competence identifications in an organization, namely: workforce expertise and resource capabilities.

Expertise or superior skills will result in superior performance. Superior skills are distinctive competences that support the company to achieve positive advantages. Positional advantage is expressed by performance outcomes which include customer satisfaction and loyalty.

Employee innovation (lecturer) plays a very big role in achieving organizational goals and high company (university) performance. Creating innovative work behaviors (IWB) is one of the best ways to encourage employee innovation levels. Innovative work behavior makes employees (lecturers) pursue proactive behavior in the form of personal initiatives and new ideas that are directly related to effective performance in organizations (Afsar et al., 2015).

Innovative work behavior among employees (lecturers) is proactive behavior in the form of personal initiative and new ideas that are directly related to effective performance in organizations (Jiménez-Jiménez and Sanz-Valle, 2011). Employee creative ideas can improve the performance of job supervisors. New ideas of innovation can take the form of new products, services, and improvements in existing procedures or processes as well as findings for efficient and effective alternative solutions for carrying out tasks. Innovative ideas allow employees (lecturers) to improve personal work performance. From the description above, the hypothesis formulated in this study are: 
H1 $_{1}$ : Innovative work behavior has a positive effect on optimal distinctive open innovation.

$\mathbf{H}_{2}$ : Optimal distinctive open innovation has a positive effect on employee work performance.

$\mathbf{H}_{3}$ : Innovative work behavior has a positive effect on employee work performance.

The following is the proposed empirical model:

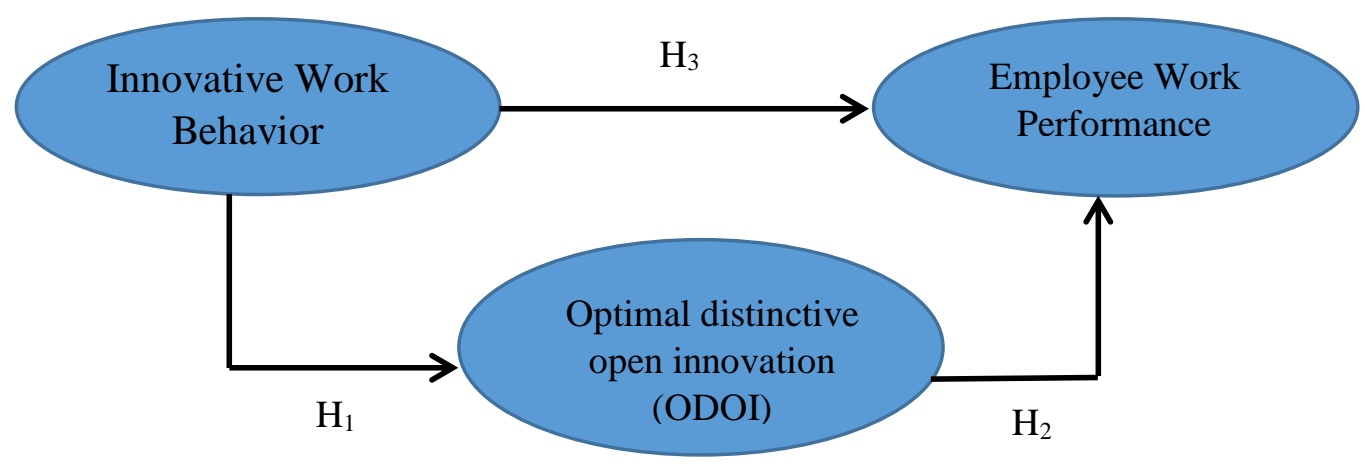

Figure 2. Empirical Research Model

\section{METHOD}

This study uses primary data obtained through a questionnaire with the object of lecturers who have academic positions in LLDIKTI VI, Central Java. The number of samples taken was 190 lecturers who were determined by purposive random sampling technique. Measurement of variables using a Likert scale of 1 to 7, Strongly Disagree = Score 1, and Strongly Agree Once = score 7.

Measurement of innovative work behavior using 4 indicators is adopted from (De Jong and Den Hartog, 2008), namely: exploration of opportunities, generation ideas, being a champion, and application ability. ODOI is measured by 6 indicators, namely: creativity creates value that is different, dynamic interactions, harmonizing cooperation, exchanging information, thinking without boundaries, and relationship complexity (Luhgiatno, 2020). Employee work performance is measured by 4 indicators adopted from (Tsui in Fuad, 2004; Sukirno and Sununta, 2011) and RI Law No. 14/2005, namely: teaching performance, research performance, publication performance, and public service performance. Furthermore, hypothesis testing uses Structural Equation Modeling (SEM) as a tool to test the relationship between complex variables and obtain a comprehensive picture of the entire model.

\section{RESULTS AND DISCUSSION}

Data Normality Test. The data normality test considers that the data equation model is sensitive to data distribution, particularly deviations from multivariate normality. This assessment uses the criterion value of the critical ratio skewness +1.96 (for an error rate of 
$5 \%$ ). The results of the assessment (table 2) show that all variables have a value below 1.96 which can be categorized in the normal range.

Table 2. Data Normality Testing

\begin{tabular}{lcccrrl}
\hline \multicolumn{1}{c}{ Variable } & Min & Max & \multicolumn{1}{c}{ skew } & \multicolumn{1}{c}{ c.r. } & \multicolumn{1}{c}{ kurtosis } & \multicolumn{1}{l}{ c.r. } \\
\hline Opportunity Exploration & 3 & 7 & $-0,182$ & $-1,023$ & $-0,189$ & $-0,531$ \\
Generation Ideas & 3 & 7 & $-0,174$ & $-0,979$ & $-0,262$ & $-0,738$ \\
Become a Champion & 3 & 7 & $-0,162$ & $-0,912$ & $-0,692$ & $-1,948$ \\
Application Capability & 4 & 7 & 0,189 & 1,062 & $-0,547$ & $-1,538$ \\
Different Creativity & 4 & 7 & $-0,167$ & $-0,94$ & $-0,73$ & $-2,053$ \\
Dynamic Interaction & 3 & 7 & $-0,314$ & $-1,765$ & $-0,268$ & $-0,753$ \\
Harmonization of Cooperation & 3 & 7 & $-0,321$ & $-1,804$ & $-0,152$ & $-0,426$ \\
Information Exchange & 4 & 7 & $-0,197$ & $-1,107$ & $-0,457$ & $-1,286$ \\
Think Without Limits & 3 & 7 & $-0,137$ & $-0,77$ & $-0,339$ & $-0,954$ \\
Relationship Complexity & 4 & 7 & $-0,137$ & $-0,772$ & $-0,47$ & $-1,322$ \\
Teaching Performance & 4 & 7 & $-0,018$ & $-0,102$ & $-0,587$ & $-1,651$ \\
Research Performance & 3 & 7 & $-0,139$ & $-0,779$ & $-0,25$ & $-0,703$ \\
Publication Performance & 3 & 7 & 0,008 & 0,048 & $-0,273$ & $-0,768$ \\
Abdimas Performance & 3 & 7 & $-0,288$ & $-1,621$ & $-0,412$ & $-1,158$ \\
Multivariate & & & & & 16,837 & 5,482 \\
\hline
\end{tabular}

Source: Primary Data Processed, 2020

Reliability Test. Reliability testing is intended to measure the internal consistency of the indicators of the shape variables which indicate the degree to which these indicators identify the shape variables. The results of this test can be seen from the value of construct reliability with a minimum cut of value of 0.70 and the required variance extracted at least 0.5 (Nunally and Bernstein, 1994). The test results (table 3) show that all the indicators used as the observed variable are relatively able to explain the construct variables it forms.

Table 3. Data Reliability Testing

\begin{tabular}{|c|c|c|c|c|c|c|}
\hline & Indicator & $\begin{array}{c}\text { Std. } \\
\text { Loading }\end{array}$ & $\begin{array}{c}\text { Std. } \\
\text { Loading }^{2}\end{array}$ & Error & $\begin{array}{l}\text { Construct } \\
\text { Reliability }\end{array}$ & $\begin{array}{l}\text { Variance } \\
\text { Extracted }\end{array}$ \\
\hline \multicolumn{7}{|c|}{ A. Innovative Work Behavior } \\
\hline 1 & Opportunity Exploration & 0,688 & 0,473 & 0,527 & \multirow{6}{*}{0,825} & \multirow{6}{*}{0,543} \\
\hline 2 & Generation Ideas & 0,710 & 0,504 & 0,496 & & \\
\hline 3 & Become a Champion & 0,810 & 0,656 & 0,344 & & \\
\hline \multirow{3}{*}{\multicolumn{2}{|c|}{4 Application Capability }} & 0,733 & 0,537 & 0,463 & & \\
\hline & & 2,941 & 2,171 & 1,829 & & \\
\hline & & 8,649 & & & & \\
\hline \multicolumn{7}{|c|}{$\begin{array}{l}\text { B. Optimal distinctive open } \\
\text { innovation }\end{array}$} \\
\hline 1 & Different Creativity & 0,708 & 0,501 & 0,499 & \multirow{8}{*}{0,902} & \multirow{8}{*}{0,536} \\
\hline 2 & Dynamic Interaction & 0,728 & 0,530 & 0,470 & & \\
\hline 3 & Harmonization of Cooperation & 0,685 & 0,469 & 0,531 & & \\
\hline 4 & Information Exchange & 0,709 & 0,503 & 0,497 & & \\
\hline 5 & Think Without Limits & 0,724 & 0,524 & 0,476 & & \\
\hline \multirow{3}{*}{\multicolumn{2}{|c|}{ Relationship Complexity }} & 0,732 & 0,536 & 0,464 & & \\
\hline & & 4,286 & 3,063 & 2,937 & & \\
\hline & & 18,370 & & & & \\
\hline
\end{tabular}


Luhgiatno, Widaryanti, Santoso: The Effect Of Odoi On Innovative Work ...

\begin{tabular}{rlrrrrr}
\hline \multicolumn{1}{c}{ Indicator } & $\begin{array}{c}\text { Std. } \\
\text { Loading }\end{array}$ & $\begin{array}{c}\text { Std. } \\
\text { Loading }^{2}\end{array}$ & Error & $\begin{array}{c}\text { Construct } \\
\text { Reliability }\end{array}$ & $\begin{array}{c}\text { Variance } \\
\text { Extracted }\end{array}$ \\
\hline C. & Employee Work Performance & & & & & \\
1 & Teaching Performance & 0,714 & 0,510 & 0,490 & & \\
2 & Research Performance & 0,692 & 0,479 & 0,521 & & \\
3 & Publication Performance & 0,752 & 0,566 & 0,434 & 0,851 & 0,500 \\
4 & Abdimas Performance & 0,707 & 0,500 & 0,500 & & \\
& & 2,865 & 2,054 & 1,946 & & \\
\hline
\end{tabular}

Source: Primary Data Processed, 2020

Model Feasibility Test. The results of structural model testing are generally proven to support the hypothesis which states that the research model fits the data (table 4).

Table 4. Structural Model Feasibility Testing

\begin{tabular}{|c|c|c|c|c|c|c|c|c|}
\hline Information & Chi-Square & Prob & GFI & AGFI & CFI & TLI & CMIN/DF & RMSEA \\
\hline Cut of Value & $\begin{array}{l}\text { Small }(\alpha=0,05 \\
D F=74)\end{array}$ & $\geq 0,05$ & $>0,90$ & & $>0,90$ & $\geq 0,95$ & $<2,00$ & $\leq 0,08$ \\
\hline $\begin{array}{l}\text { Analysis } \\
\text { results }\end{array}$ & $88,758<95,081$ & 0.116 & 0,937 & 0,910 & 0,985 & 0,982 & 1,199 & 0,032 \\
\hline Conclusion & Fit & Fit & Fit & Fit & Fit & Fit & Fit & Fit \\
\hline
\end{tabular}

Source: Primary Data Processed, 2020

Analysis Squared Multiple Correlation. Analysis of the ability to explain antecedent variables to consequent variables in this study can be seen from the value of $R$ square $\left(\mathrm{R}^{2}\right)$ (table 5). The value of $\mathrm{R}^{2}$ for the ODOI variable is 0.229 , meaning that the innovative work behavior variable is able to explain its impact on the ODOI variable by $22.9 \%$ expressed in the moderate group $\left(21 \%<\mathrm{R}^{2}<40 \%\right)$. While the $\mathrm{R}^{2}$ value for the employee work performance variable is 0.249 , meaning that the innovative work behavior variable and the ODOI variable are able to explain the impact on the employee work performance variable by $24.9 \%$ which is also stated in the moderate group.

Table 5. Squared Multiple Correlation (Smc) Testing

\begin{tabular}{lr}
\hline \multicolumn{1}{c}{ Variabel } & Estimate \\
\hline Optimal distinctive open innovation (ODOI) & 0,229 \\
Employee Work Performance & 0,249 \\
\hline Source: Primary Data Processed, 2020
\end{tabular}

Source: Primary Data Processed, 2020 


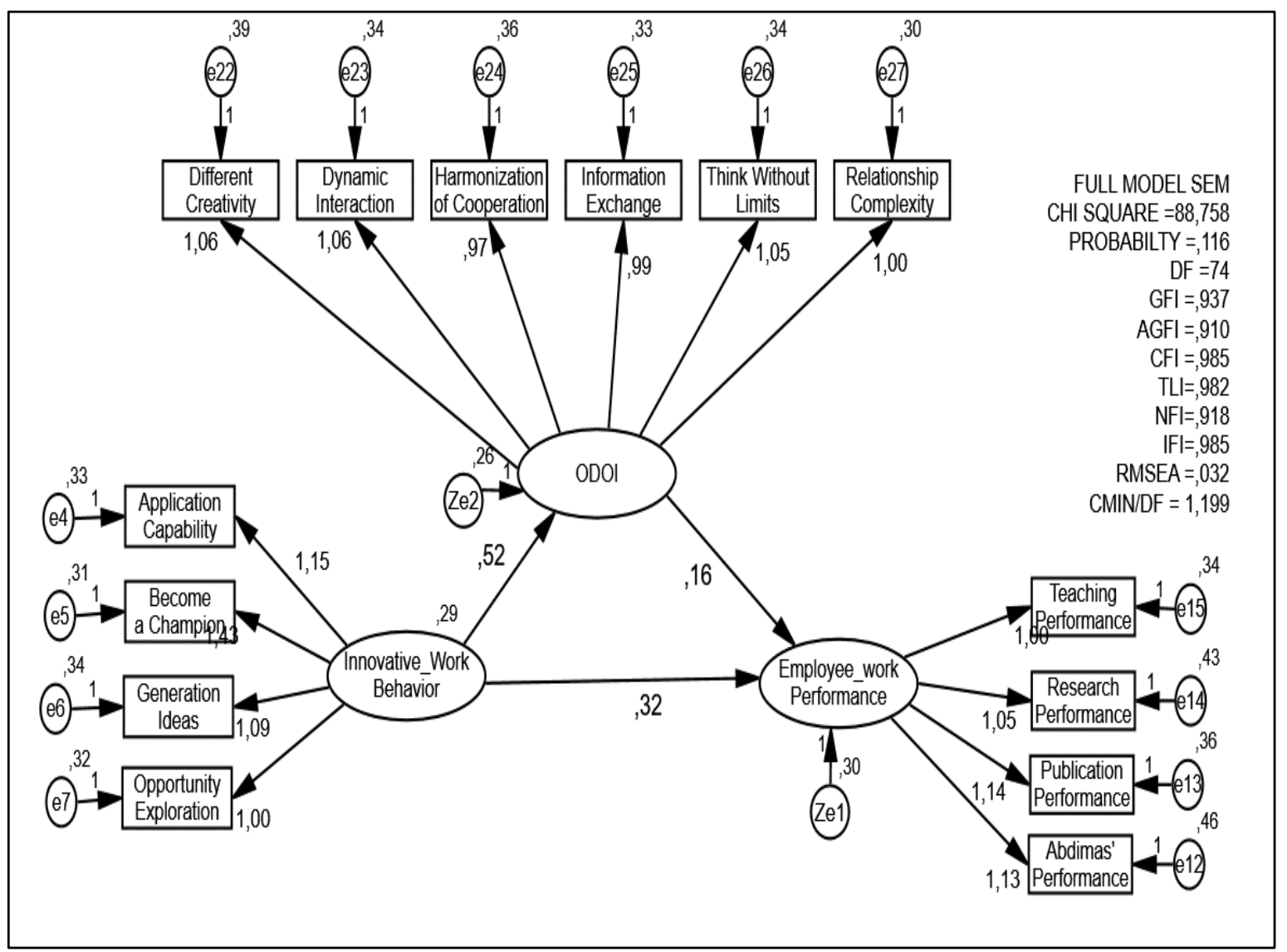

Figure 3. Full SEM Model Testing

Parameter Analysis of the Research Model. The results of data processing to test 3 (three) hypotheses with AMOS 22 are shown in (table 6). The structure of the equation for the causality relationship is in standardized form as in the following equation:

1. ODOI $=0,479$ IWB $+\square_{1} \rightarrow \mathrm{p}=* * *$ (sig)

2. EWP $=0,287$ IWB $+0,256$ ODOI $+\square_{2} \quad \rightarrow$ p $=0,006$ (sig) and $\mathrm{p}=0,018$ (sig)

Information:

ODOI = Optimal distinctive open innovation

IWB = Innovative work behavior

EWP $=$ Employee work performance 
Table 6. Parameter Analysis Results of the Model

\begin{tabular}{lcccccc}
\hline \multicolumn{1}{c}{ Causality Relationship } & $\begin{array}{c}\text { Koef. B } \\
\text { Unstdrz }\end{array}$ & $\begin{array}{c}\text { Koef. B } \\
\text { Stdrz }\end{array}$ & S.E. & $\begin{array}{c}\text { Critical } \\
\text { Ratio. }\end{array}$ & $\begin{array}{c}\text { P } \\
\text { Value }\end{array}$ \\
\hline $\begin{array}{l}\text { Optimal distinctive } \\
\text { open innovation } \\
\text { (ODOI) }\end{array}$ & $\leftarrow \begin{array}{l}\text { Innovative work } \\
\text { behavior (IWB) }\end{array}$ & 0,522 & 0,479 & 0,101 & 5,144 & $* * *$ \\
$\begin{array}{l}\text { Employee work } \\
\text { performance } \\
(\text { EWP })\end{array}$ & $\begin{array}{l}\text { Innovative work } \\
\text { behavior (IWB) } \\
\begin{array}{l}\text { Optimal distinctive } \\
\text { open innovation } \\
\text { (ODOI) }\end{array}\end{array}$ & 0,319 & 0,287 & 0,117 & 2,729 & 0,006 \\
\hline Soure: Primar & 0,259 & 0,256 & 0,102 & 2,561 & 0,018 \\
\hline
\end{tabular}

Source: Primary Data Processed, 2020

\section{Hypothesis testing}

The influence of innovative work behavior on ODOI. Estimation of testing the effect of innovative work behavior on ODOI showed significant results with the obtained standardized estimate value of 0.479 , critical ratio $(\mathrm{CR})$ of 5.144 and p-value $=* * *$. These values have met the requirements for acceptance of the hypothesis, namely the value of $\mathrm{CR}>1.96$ at a significance level of 0.05 (p-value $<0.05$ ). So that hypothesis $1\left(\mathrm{H}_{1}\right)$ is accepted, which means that there is a significant influence on innovative work behavior on ODOI.

The empirical findings in the research show that if lecturers can improve their ability to explore opportunities, increase generation ideas, increase the desire to become champions and increase application capabilities, they will be able to increase their ability to openly innovate with the most optimal peculiarities. In essence, the situation in the campus environment is always developing. The rapid development of technology (one of them) requires a lecturer to always explore opportunities with new ideas (naughty ideas), who are more daring to be different so that they grow to be champions. This naughty idea, for example, can be realized in terms of collaboration with other lecturers between different study programs to conduct joint research. Lecturers from the accounting study program collaborated with lecturers from the health program to conduct research on the impact of the covid-19 outbreak on the efficiency of business management of a company. A lecturer is required to always improve his applicative ability at all times and opportunities in carrying out tridharma duties. The goal is that Lecturers are increasingly competent in their duties and responsibilities. They will be more able to innovate openly, have more special colors/uniqueness to be developed optimally.

The effect of ODOI on employee work performance. Testing the effect of ODOI on employee work performance showed significant results by obtaining a standardized estimate value of 0.256 , a critical ratio $(\mathrm{CR})$ of 2.561 and $\mathrm{p}$-value $=0.018$. So that hypothesis $2\left(\mathrm{H}_{2}\right)$ is accepted, which means that there is a significant effect of ODOI on employee work performance. In line with research (Janssen, 2003), trust motivates employees to collaborate/dynamic interaction and support each other's ideas through reciprocity and knowledge sharing will improve performance. Innovative employee work behavior is analogous to when interpersonal relationships within high-quality team members and among co-workers are created harmonious cooperation (Janssen et al., 2004; 
Scott and Bruce, 1994), as well as between work teams and organizational teams (Zakaria et al., 2004).

The empirical findings in the study show that if lecturers can increase creativity in creating different values, dynamic interactions, harmonizing cooperation, exchanging information, thinking without boundaries and the complexity of relationships, it can improve employee work performance. They have unique/different creativity for means of self-actualization, for example: in the fields of marketing, pharmacy, IT, information systems, graphic design, and others. Lecturers must always interact dynamically to explore opportunities in developing/finding new ideas /ideas. Dynamic interaction by maintaining harmonization in cooperation is very necessary to be carried out internally by universities, between universities, partner organizations (business/industrial world), community organizations and government organizations, as well as professional organizations that they participate in.

Given the complexity of the relationship that tends to increase and the exchange of information is fast and massive, it requires lecturers to get used to thinking without limits (out of the box) in order to find new ideas/ ideas in improving employee work performance. Research activities can be carried out by collaborating with fellow lecturers who have different disciplines (for example, accounting disciplines collaborating with chemical engineering disciplines). Meanwhile, the complexity of the relationship occurs because of: additional tasks that consume energy, the organizational culture that has been formed, seniority in the organization, different personal needs/ interests/motivations/goals, duties and responsibilities within the organization, and conflicts between individuals in one organization. Information exchange is often carried out in terms of material exchange and lecture administration, research and community service, cooperation between institutions and collaborative program activities, publication of scientific works, inventions and creations, student handling, and developments in science and technology.

The influence of innovative work behavior has a positive effect on employee work performance. The results of empirical test proved that innovative work behavior on employee work performance showed significant results by obtaining a standardized estimate value of 0.287 , a critical ratio $(\mathrm{CR})$ of 2.729 and $\mathrm{p}$-value $=0.006$. So that hypothesis $3\left(\mathrm{H}_{3}\right)$ is accepted, which means that there is an effect of innovative work behavior on employee work performance which has been shown to be significant. The results of this test are in line with research (Clegg et al., 2002) finding that when employees believe that their coworkers listen to and support their ideas and attribute the importance of any novelty suggestions they propose, they are more motivated to improve their work performance. Employees who are trusted to provide suggestions for improving the quality of procedures and processes in an organization will feel an increase in motivation (Thomas and Velthouse, 1990) which can improve their work performance.

The empirical findings in this study indicate that increasing the ability to explore opportunities carried out by a lecturer as well as efforts to increase generation ideas, increasing the desire to become champions and increasing application abilities will be able to improve employee (lecturer) work performance. The rapid development of technology (one of them) requires a lecturer to always explore opportunities with new ideas (naughty ideas) who are more daring to be different so that they grow to be champions in carrying out the duties of the Tridharma of Higher Education. This new idea must emerge to sustain 
teaching performance, research performance, publication performance and public service performance. For example, lecturers from management study programs have new ideas to increase the effectiveness of the learning process in class or new ideas/ findings about research topics that have practical benefits for community life. Lecturers are also constantly required to always improve their competence in their duties and responsibilities.

Mediation Variable Test. Mediation testing uses an analysis of the indirect effect, direct effect and total effect. The direct effect is the regression weight or path coefficient. The sum of the direct effects and the indirect effects is the total effect (table 7).

Table 7. Direct Effect, Indirect Effect and Total Effect

\begin{tabular}{clc}
\hline Construct & \multicolumn{1}{c}{ Influence } & Innovative Work Behavior \\
\hline \multirow{2}{*}{ Employee Work } & Direct & 0,319 \\
Performance & Indirect & 0,083 \\
& Total & 0,402 \\
\hline
\end{tabular}

Source: Primary Data Processed, 2020

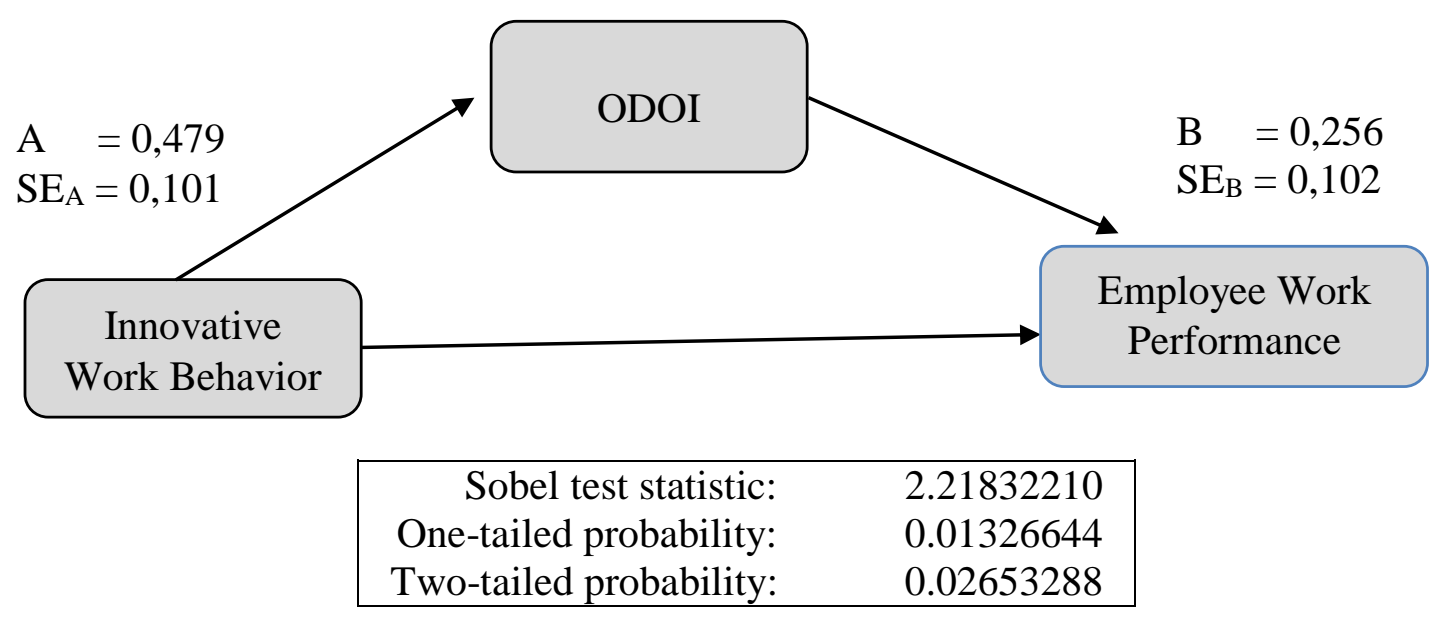

Figure 4. Detection of the Effect of ODOI Mediation on the Relationship between Innovative Work Behavior and Employee Work Performance

Based on the estimation results, the direct influence of the innovative work behavior variable on employee work performance shows a positive and significant effect with a value of 0.319 and $\mathrm{p}$-value $=0.006$. The indirect effect of innovative work behavior variables on employee work performance with ODOI mediation obtained a value of 0.083 , and a total effect of 402.The Sobel test to test the significance of the mediating variable (figure 4), it can be explained that ODOI proved significant as a mediator to bridge the gap innovative work behavior variables with employee work performance variables. This can be seen in the p-value of 0.02653288 , which is below 0.05 . The results of the mediation test provide a signal on the importance of the ODOI variable as a mediator for the 
relationship between innovative work behavior variables and employee work performance variables.

\section{CONCLUSION}

Synthesis of the distinctive optimal concept derived from social identity theory, and open innovation which is derived from innovation theory, a proposition optimal distinctive open innovation (ODOI) can be generated as a new concept. The test results from empirical research show that open innovation with optimal peculiarities is able to mediate the effect of innovative work behavior on improving employee work performance. Innovative work behavior has an effect on increasing ODOI and has an effect on improving employee work performance. ODOI has an effect on improving employee work performance, and is able to act as a catalyst/liaison for improving employee work performance.

Future Research Agenda. ODOI has been tested empirically as a catalyst/mediator between innovative work behavior and employee performance variables. The development of an empirical model in this study allows further research to be carried out related to: (1) ODOI as an independent variable that directly affects other dependent variables. (2) Comparative study for lecturer respondents from State Universities and Private Universities. (3) Research conducted for non-lecturer respondents or employees of nonuniversity organizations.

\section{REFERENCES}

Afsar, B., Badir, Y., and Khan, M. M. (2015). Person-job fit, person-organization fit and innovative work behavior: The mediating role of innovation trust. The Journal of High Technology Management Research, 26(2), 105-116.

Altındağa, E., and Kösedağı, Y. (2015). The relationship between emotional intelligence of managers, innovative corporate culture and employee performance. ProcediaSocial and Behavioral Sciences, 210, 270-2822.

Ardyan, E. (2016). Market sensing capability and SMEs performance: The mediating role of product innovativeness success. DLSU Business and Economics Review, 25(2), 118.

Badea, C., Jetten, J., Czukor, G., and Askevis-Leherpeux, F. (2010). The bases of identification: When optimal distinctiveness needs face social identity threat. British journal of Social Psychology, 49(1), 21-41.

Barnett, H., G., (1953). Innovation. Mcgraw-Hill.

Burcharth, A., Knudsen, M. P., and Søndergaard, H. A. (2017). The role of employee autonomy for open innovation performance. Business Process Management Journal, 23(6), 1245-1269.

Burke, PJ., and Stets, JE., (2006). Identity Theory And Social Identity Theory. Washington State University.

Cassiman, B., and Valentini, G. (2016). Open innovation: are inbound and outbound knowledge flows really complementary? Strategic Management Journal, 37(6), 1034-1046. 
Chen, X. H., Zhao, K., Liu, X., and Wu, D. D. (2012). Improving employees' job satisfaction and innovation performance using conflict management. International Journal of Conflict Management, 23(2), 151-172.

Chesbrough, H. (2003). Open innovation: Boston: Harvard Business School Press.

Choudhary, N., Naqshbandi, M. M., Philip, P. J., and Kumar, R. (2017). Employee job performance: The interplay of leaders' emotion management ability and employee perception of job characteristics. Journal of Management Development, 36(8), 10871098.

Clegg, C., Unsworth, K., Epitropaki, O., and Parker, G. (2002). Implicating trust in the innovation process. Journal of Occupational and Organizational Psychology, 75(4), 409-422. doi:10.1348/096317902321119574.

Ebrahimi, Z. F., Chong, C. W., and Rad, R. H. (2014). TQM practices and employees' role stressors. International Journal of Quality dan Reliability Management, 31(2), 166183.

Ferrari, A., Cachia, R., and Punie, Y. (2009). Innovation and creativity in education and training in the EU member states: Fostering creative learning and supporting innovative teaching. JRC Technical Note, 52374.

Hair, J. F. J., Anderson, R. E., Tatham, R. L., and Black, W. C. 1998. Multivariate Data Analysis, 5th edition, Upper Saddle River: Prentice Hall.

Hogg, M., A., and Vaughan, G., M., (2002). Social Psychology. Prentice Hall.

Iqbal, A., and Asrar-ul-Haq, M. (2018). Establishing relationship between TQM practices and employee performance: The mediating role of change readiness. International Journal of Production Economics, 203, 62-68.

Janssen, O. (2003). Innovative behavior and job involvement at the price of conflict and less satisfactory relations with co-workers. Journal of Organizational and Occupational Psychology, 76: 347-364.

Janssen, O.,Vande Vliert, E., and West, M. (2004).The bright and dark sides of individual and group innovation: A special issue introduction. Journal of Organizational Behavior, 25: 129-145.

Jiménez-Jiménez, D., and Sanz-Valle, R. (2011). Innovation, organizational learning, and performance. Journal of business research, 64(4), 408-417.

Leonardelli, G. J., Pickett, C. L., and Brewer, M. B. (2010). Optimal Distinctiveness Theory: A Framework for Social Identity, Social Cognition, and Intergroup Relations. In M. P. Zanna dan J. M. Olson (Eds.), Advances in Experimental Social Psychology (Vol. 43). San Diego: Academic Press.

Luhgiatno. (2020). Inovasi terbuka dengan kekhasan yang optimal sebagai katalisator peningkatan perilaku kerja inovatif. Salatiga: FEB - UKSW.

Messmann, G., and Mulder, R. H. (2011). Innovative work behaviour in vocational colleges: Understanding how and why innovations are developed. Vocations and Learning, 4(1), 63-84.

Mikhaylov, F., Julia, K., and Eldar, S. (2014). Current tendencies of the development of service of human resources management. Procedia-Social and Behavioral Sciences, 150, 330-335.

Nunnally, Bernstein, I.H. (1994). Psychometric Theory, Edisi ke 3. New York: McGraw Hill. 
Pownall, I., Kennedy, V., and Acquaye, D. (2019). Do new first year students seek optimal distinctiveness in a new learning environment? The International Journal of Management Education, 17, 254-266.

Rogers, E., M. (1983). Diffusion of Innovations. London: The Free Press.

Rusu, G., Avasilcăi, S., and Huțu, C.-A. (2016). Organizational context factors influencing employee performance appraisal: A research framework. Procedia-Social and Behavioral Sciences, 221, 57-65.

Sadikoglu, E., and Zehir, C. (2010). Investigating the effects of innovation and employee performance on the relationship between total quality management practices and firm performance: An Empirical study of Turkish firm. International Journal of Production Economics, 127(1), 13-26.

Schepers, J. J. L., Nijssen, E. J., and Van der Heijden, G. A. H. (2016). Innovation in the frontline: Exploring the relationship between role conflict, ideas for improvement, and employee service performance. International Journal of Research in Marketing, 33(4), 797-817.

Scott, S. G., and Bruce, R. A. (1994). Determinants of innovative behavior: A path model of individual innovation in the workplace. Academy Of Management Journal, 37(3), 580-607.

Slater, S. F., Mohr, J. J., and Sengupta, S. (2014). Radical product innovation capability: Literature review, synthesis, and illustrative research propositions. Journal of Innovation Management, 31(3), 552-566.

St-Onge, S., and Morin, D. (2009). Manager's motivation to evaluate subordinate performance. Qualitative Research in Organizations and Management: An International Journal, 4(3), 273-293.

Sugiyarti, G., and Ardyan, E. (2017). Market sensing capability and product innovation advantages in emerging markets: The case of market entry quality and marketing performance of Batik Industry in Indonesia. DLSU Business and Economics Review, 27(1), 175-189.

Thomas, K. W., and Velthouse, B. A. (1990). Cognitive elements of empowerment. Academy of Management Review, 15: 666-681.

Tsinopoulos, C., Yan, J., and Sousa, C. M. P. (2019). Abandoning innovation activities and performance: The moderating role of openness. Research Policy, 48(6), 13991411 .

Vähäsantanen, K., and Eteläpelto, A. (2009). Vocational teachers in the face of a major educational reform: Individual ways of negotiating professional identities. Journal of Education and Work, 22(1), 15-33.

Van De Vrande, V., DeJong, J. P., Vanhaverbeke, W., and DeRochemont, M. (2009). Open innovation in SMEs: trends, motives and management challenges. Technovation, 29(6), 423-437.

Zakaria, N., Amelinckx, A., and Wilemon, D. (2004). Working Together Apart? Building a Knowledge-Sharing Culture for Global Virtual Teams. Creativity and Innovation Management, 13(1), 15-29. doi:10.1111/j.1467-8691.2004.00290.x. 